\title{
Unexpected Defeat: The Unsuccessful War Crimes Prosecution of Lt Gen Yamawaki Masataka and others at Manus Island, 1950 \\ Narrelle Morris*
}

The Australian war crimes trials programme of accused Japanese war criminals conducted after World War II was a massive undertaking, encompassing 300 B and C class trials held at Morotai, Wewak, Labuan, Rabaul, Darwin, Singapore, Hong Kong and Manus Island in the period 1945-51. In military trials convened pursuant to the Australian War Crimes Act 1945 (Cth), 813 Japanese were tried and 141 were eventually sentenced to death and executed. ${ }^{1}$ Undoubtedly like all the international and national war crimes trials held in the post-war period, the Australian trials programme had to deal with a number of ongoing difficulties, well beyond the often complex factual and legal issues with which the courts and tribunals usually grappled. One of the most pivotal and ongoing constraints on the Australian trials programme was the location of suitable places to convene and hold courts, given that the stated intention of the programme from the start was to hold the trials as proximate to the place of offence as possible. After 1 Australian War Crimes Section (1AWCS) was instructed by the British authorities to leave Singapore in 1947 and then to leave Hong Kong in 1948, however, there was an interim of a year and a half during which no trials took place, more or less for want of a trial location, although there were other impeding factors. After repeatedly failing to obtain the permission of the Supreme Commander of Allied Powers (SCAP), Gen Douglas MacArthur, for Australian trials to be convened in Japan, the final series of twenty-six trials was eventually held at Manus Island in 1950-51, long after the other national war crimes trials programmes had ceased.

Under international pressure, principally from the United States, and some internal pressure in Australia to cease the war crimes trials programme altogether, the Manus Island trials were carefully selected from a shortlist of possible prosecution cases, designed to produce certain

\footnotetext{
*Dr Narrelle Morris (nemorris@unimelb.edu.au) is an Honorary Research Fellow in the Asia Pacific Centre for Military Law, Melbourne Law School at The University of Melbourne, where she is the principal legal researcher on the project Australia's Post-World War II War Crimes Trials of the Japanese: A Systematic and Comprehensive Law Reports Series. The author thanks the National Archives of Australia for their conferral of the Ian Maclean Award for 2011-12 which assisted her in conducting the research for this article and the anonymous reviewers for their comments.

${ }^{1}$ These figures have been freshly calculated by the author. Some accused were tried more than once and some received multiple death sentences.
} 
convictions followed by death sentences. The consequent acquittal - twice - of Lt Gen Yamawaki Masataka (1886-1974) and some of his subordinates at Manus Island on charges of murdering Australian Army officers and soldiers or failing to try them properly and fairly for alleged crimes before executing them was, at the time, very unexpected. This article examines how and why one of these two prosecution cases against Yamawaki and his co-accused was selected for trial and assesses how this supposedly watertight case was misjudged in the pre-trial phase to the extent that it resulted in easy acquittals. The failed prosecution demonstrates just how difficult it was, and still can be, to reconcile perceptions that a war crime had been committed and expectations of conviction and punishment with the reality of dealing with international criminal law, and all its ambiguities, as it stood in the mid-twentieth century, and as it still stands today. Moreover, this case demonstrates that the application of international criminal law to individuals after war can, indeed, rise above the oft-repeated adage of victors' justice when the courts and tribunals which interpret and implement the law do not simply operate from the presumption that an act by the enemy which appears abhorrent to one's own side is necessarily and inevitably a war crime deserving of punishment.

\section{The Resumption of Trials at Manus Island}

Somewhat paradoxically given the international pressure to cease the Australian war crimes trials, the effective impetus for their resumption came in September 1949 from Gen MacArthur, who threatened to release the 87 Japanese suspected war criminals then being detained on Australia's behalf in Sugamo Prison in Tokyo if Australia did not remove them for trial or release them. ${ }^{2}$ Australia's delay in bringing the suspects to trial was said to represent a fundamental denial of justice to those who were detained, some for already lengthy periods. As SCAP's Diplomatic Section pointed out to the Australian Mission in Tokyo in October 1949:

\footnotetext{
${ }^{2}$ See cable from Australian Mission, Tokyo, to the Department of External Affairs, 20 September 1949, National Archives of Australia (NAA): A816, 19/304/447.
} 
More than four years after the termination of hostilities and from one to two years after the original apprehension of the majority of the suspects, their continued incarceration without specific charges and without even a certain prospect of eventual trial can scarcely be reconciled with fundamental concepts of justice. ${ }^{3}$

One of MacArthur's unnamed but 'top legal advisers' cut to the heart of the issue even more bluntly, questioning:

how can we sell democratic justice to the Japanese if Australia flouts all the rules of the game for more than four years? ${ }^{4}$

MacArthur and his legal staff had concluded that there were just 'about eight cases' involving Australia's detained suspects which 'merit[ed] trial'. In their view, the evidence in the other cases was such that they were 'doubtful of conviction' or, even if convictions were achieved, the periods of imprisonment that would follow were a 'portion' of time that the detainees had already served in custody. ${ }^{5}$ Lt Gen H. C. H. Robertson, the Australian Commander-in-Chief of the British Commonwealth Occupation Force in Japan, reviewed SCAP's list of potential cases and forwarded his own list of nine cases home to Australia, which included the case involving Yamawaki discussed in this article. ${ }^{6}$ After considerable wrangling and controversy, a final list of twenty-three trials for Manus Island was approved by the Australian Prime Minister, Robert Menzies, although some of these cases were eventually split at trial.

The final shortlist of cases for Manus Island was deliberately selective on three grounds: the victim or victims should be preferably Australian and service personnel, not civilians; there should be a high probability of conviction and, if convicted, a death sentence ‘might appropriately' be awarded. As Menzies explained to the House of Representatives on 25 February 1950, the Government had decided to proceed with trials at Manus Island against suspected war criminals

\footnotetext{
${ }^{3}$ Cable from Australian Mission, Tokyo, quoting full text of correspondence from the Diplomatic Section of G.H.Q. Supreme Commander for the Allied Powers, to the Department of External Affairs, 22 October 1949, NAA: A816, 19/304/447.

${ }^{4}$ Quoted in Melbourne Herald, 4 January 1950 in NAA: A1838, 3103/10/13/2 PART 1.

${ }^{5}$ Cipher message Z96 from British Commonwealth Occupation Force to Defence Melbourne, 29 October 1949, NAA: A816, 19/304/447.

${ }^{6}$ This case was known as 'A4', see 'Cases Recommended by Lt. Gen. H.C.H. Robertson for Trial' attached to cipher message Z102 from BCOF to Army Melbourne, 21 November 1949, NAA: A816, 19/304/447.
} 
who faced 'capital charges'; that is, charges of murder or other 'revolting crimes' where the 'death sentence would be appropriate'. ${ }^{7}$ Those suspects against whom adequate evidence had not been gathered despite the passage of years would be released.

Hopes were apparently high for the Manus Island trials. It was widely reported in June 1950, just before they commenced, that the Australian Government was:

confident that the evidence for the prosecution is strong and watertight. It anticipates some death sentences and has already appointed a hangman. ${ }^{8}$

The Government realised almost immediately that public reports about the appointment of a hangman gave the impression that the outcome of the trials - convictions and executions - was a foregone conclusion and it was swiftly announced that if, indeed, a hangman had been appointed for Manus Island, the appointment would be cancelled. ${ }^{9}$ The Australian Army, which was again running the war crimes trials, appeared to have learned a valuable lesson about appearances, as an internal memorandum a few days later advised that it was not proposed that a gallows should be erected at Manus Island until such time as a sentence of death by hanging had been confirmed. ${ }^{10}$

\section{The Prosecution of Lt Gen Yamawaki Masataka}

Two of the cases eventually listed for trial at Manus Island concerned Yamawaki who, in 1944, had been the General Officer Commanding (GOC) of the Japanese $37^{\text {th }}$ Army, headquartered in Jesselton, British North Borneo. Yamawaki had been the Japanese Vice-Minister of War in 1938-39

\footnotetext{
7 ‘Australian Policy on War Trials’, The West Australian, 25 February 1950, p. 1.

8 'Japanese Hopes for War Trials', The Advertiser (Adelaide), 3 June 1950, p. 4.

${ }^{9}$ As reported in 'No Hangman Post at War Crimes Trials', Sydney Morning Herald, 7 June 1950, p. 3. The Australian Army had asked the Department of External Territories in March 1950 to 'make available a suitable officer' to carry out any death sentences by hanging and External Territories subsequently advised the Army on 12 May 1950 that Mr T. W. Upson would be made available. Upson then placed certain conditions on his agreement and, by the time the Upson's supposed appointment was publicised in early June 1950, the negotiations were, in fact, still ongoing. As the Secretary of the Department of the Army was advised, statements that Upson had been appointed were thus 'incorrect', although negotiations had been in process to that effect since 29 March 1950. It was explained that the process had begun before the trials so that 'in the event of the negotiations being protracted, inhumane delays caused by a hangman not being available would not occur in the carrying out of any death sentences that may be confirmed': see Memorandum for the Secretary, 'Trials of Japanese Suspect Minor War Criminals', 7 June 1950 in AWM: AWM166, 4.

${ }^{10}$ Memorandum for the Secretary, 'War Crimes Trials - Manus Island', 13 June 1950 in AWM: AWM166, 4.
} 
but his 'chief celebrity', apart from in the field of war crimes, is that the conception of the AntiComintern Pact has been attributed to him. ${ }^{11}$
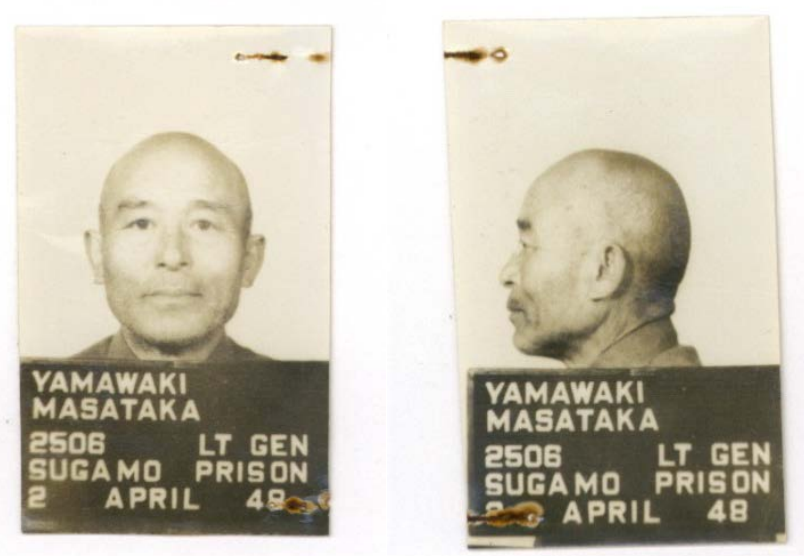

Figure 1: War crimes suspect photos of Lt Gen Yamawaki Masataka (山脇正隆) ${ }^{12}$

In a trial at Manus Island that was held from 16-18 October 1950, Yamawaki and three of his staff officers - Lt Col Maeda Toshimitsu, Capt Matsumoto Tomeyoshi and Lt Kanazawa Kisou - were tried for the murders of three Australian Army soldiers at Jesselton or, alternatively, for violating the laws and usages of war by disregarding and failing in their duty to try the soldiers in accordance with international law whereby they were unlawfully executed.

The victims in this case were Lt Alfred Rudwick, Sgt Donald McKenzie and Sgt William Brandis, all members of the Services Reconnaissance Department (SRD), a special forces precursor to the modern Australian Special Air Service Regiment (SAS). Rudwick, McKenzie and Brandis had been captured in Japanese-occupied Borneo in early 1944 while engaged in intelligence reconnaissance work in an operation named Python II. $^{13}$

\footnotetext{
${ }^{11}$ Ben Bruce Blakeney, 'The Japanese High Command', 9(1) Military Affairs (Summer 1945) 95-113, at 112. Yamawaki was the military attaché in Warsaw in 1934-35.

${ }^{12}$ Images held in NAA: MP375/11, 10.

${ }^{13}$ For a history of the Python operations, see A. B. Feuer, Australian Commandos: Their Secret War Against the Japanese in World War II (Mechanicsburg, PA: Stackpole, 2006).
} 


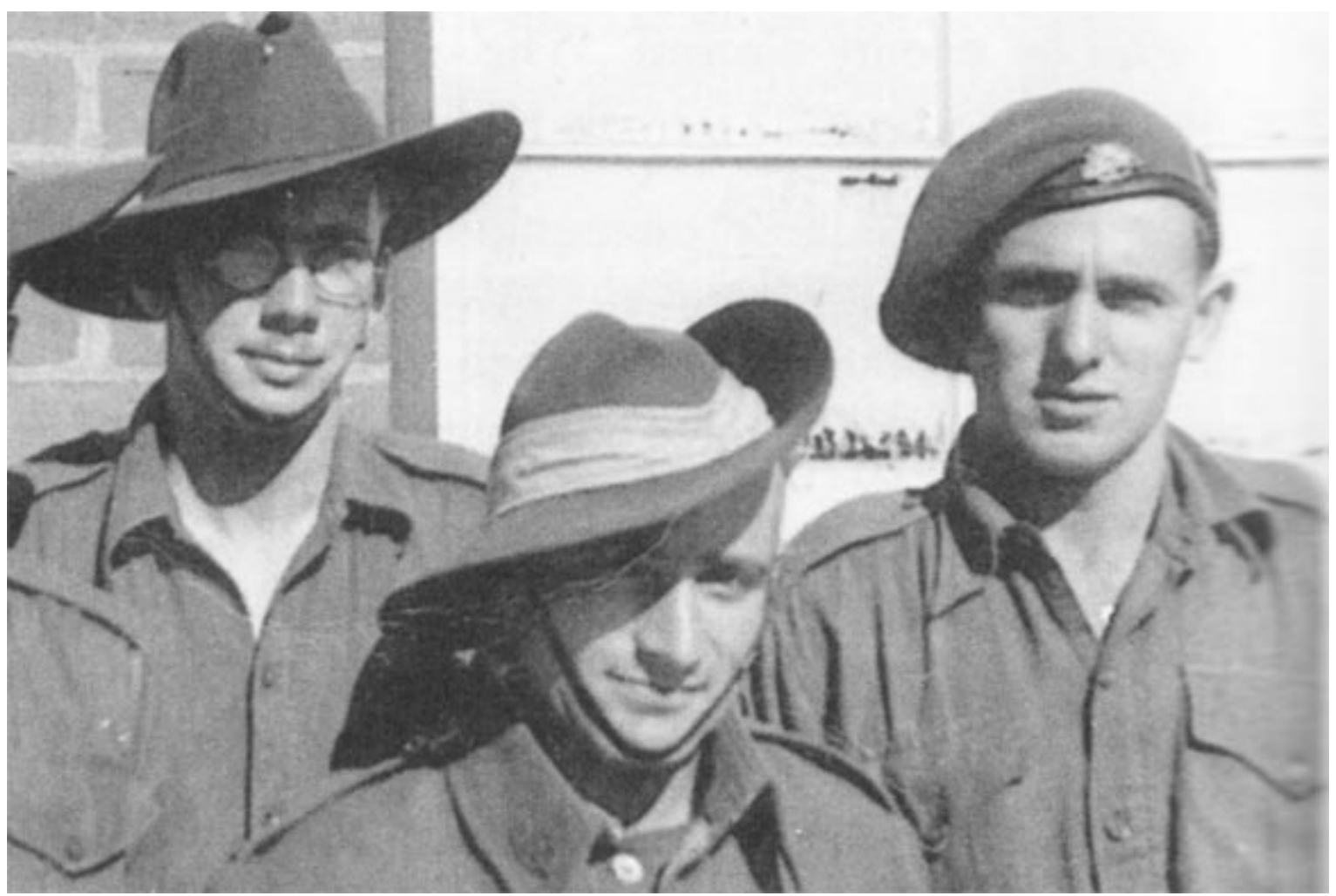

Figure 2: WX40238 Sgt Donald McKenzie, VX102007 Lt Alfred (Jack) Rudwick and WX16743 Sgt William Brandis

It is uncontested that their squad (and that of the earlier Python I party) had landed secretly by submarine in Borneo, they had observed Japanese movements and they had transmitted that information back to Australia, apart from Brandis who got lost in the jungle the day after he arrived. Although accounts of their capture and interrogation stem principally from Japanese witnesses, it is also generally uncontested that when they were captured only Rudwick and McKenzie were still dressed in Australian Army jungle greens (although the Japanese did not recognise the clothing as Army uniform); Brandis had lost most of his clothing while swimming a river after becoming lost. In addition, none of the three wore or carried any Army badges of rank, insignia or any identification discs or other identity documents, such as paybooks. If the Japanese accounts of their interrogation can be believed, they apparently explained to their captors that they had taken off their insignia of rank as, if they were 'found to be soldiers', they would be 'discovered' and 'captured. ${ }^{\text {,14 }}$ Rudwick apparently told the Japanese that he had 'wanted to avoid being observed as an enemy soldier in Borneo' and that:

\footnotetext{
${ }^{14}$ Reported in the statement of WO Kuroda Shintarô, p. 12, NAA: A471, 81956.
} 
We are soldiers, ordered here to carry out a military task, to avoid displaying army insignia and badges of rank ... and should therefore not be treated as spies but as prisoners of war as required by International Law. ${ }^{15}$

The prosecuting officer at Yamawaki’s war crimes trial at Manus Island, Maj H. J. Foster, submitted in his opening address ${ }^{16}$ that while Yamawaki’s legal officer, Matsumoto, knew the circumstances of the capture of the three Australian soldiers and understood the provisions of international law relating to espionage in that 'soldiers not in disguise carrying out reconnaissance in enemy territory are not spies', he had advised Yamawaki that the prisoners should be tried for espionage. Yamawaki then convened a military court - comprising Maeda as president, Kanazawa as a junior member and Matsumoto as prosecutor - which tried the prisoners in Jesselton in December 1944. The prosecuting officer then submitted that while Yamawaki and his co-accused had a duty to ensure that the prisoners were tried in accordance with international law, they had wilfully failed to discharge that duty by failing, for example, to properly enquire into the status of the prisoners. In particular, he highlighted their failure to ask questions of their own intelligence officers about Australian Army uniforms. He considered that the prisoners'status as soldiers ought to have been so obvious that no reasonable man could honestly have believed them to be spies. Moreover, in the prosecuting officer's view, the Japanese trial of the three soldiers was simply a 'mock' or a 'sham' trial, not a fair and proper trial as required by international law, as a consequence of which the soldiers were convicted of espionage, sentenced to death and hanged close to Christmas in 1944. The prosecuting officer thus submitted that, given the unlawfulness of the so-called trial, the executions were unlawful and, in fact, constituted murder. The families of the three soldiers had been simply told at the time that they had '[d]ied whilst a prisoner of war'. ${ }^{17}$

Yamawaki's war crimes trial at Manus Island was meant to be, as modern prosecutorial parlance would put it, a sure thing. Although he and his co-accused were meant to be convicted,

\footnotetext{
${ }^{15}$ As quoted in the summary of examination of former Capt Matsumoto Tomeyoshi, pp. 2-3, NAA: A471, 81956.

${ }^{16}$ NAA: A471, 81956.

${ }^{17}$ See Memorandum for the Secretary, 'Publication of Names of AMF Personnel - Manus Trials', 14 June 1950 in AWM: AWM166, 4.
} 
albeit fairly and properly and with due legal process, the charges were dismissed on the defence's application at the end of Foster's prosecution case; the accused did not even have to present their defence before the trial was over. The Court itself, led by the President, Brigadier Kenneth Townley, ordinarily a judge of the Supreme Court of Queensland, more or less demolished the prosecution case from the bench on the basis that no war crime had been committed. The Canberra Times and a number of other newspapers advised their readers that Yamawaki's trial had 'dramatically ended' with the Court holding that the accused had 'no case to answer'. ${ }^{18}$ Yamawaki apparently heard this decision 'unmoved' but 'smiled slightly' as he left the dock. ${ }^{19}$

\section{Why did the Prosecution Fail?}

So what happened in Yamawaki's case to turn what the Australian Government, amongst others, believed would be a 'strong and watertight' conviction for committing a war crime into a failed prosecution? Can this unexpected turn of events be attributed to an insufficient gathering of evidence, to poor quality evidence or to a rushed assessment of that evidence? On the face of it, no. Perhaps most crucially, all 23 cases initially listed for trial at Manus Island had already been judged as having adequate evidence and, moreover, this case against Yamawaki and his co-accused was among those specifically approved by MacArthur and his legal staff and, in turn, by Robertson. Nor was the investigation conducted in a hasty or perfunctory manner and rushed to trial. By the time Yamawaki's trial eventually commenced in 1950, more than five years had passed since the end of the war. Admittedly, in the early stages of Australian investigations into Japanese war crimes, it appeared likely that Yamawaki would be tried internationally as a major war criminal because of his position of command responsibility. ${ }^{20}$ Only mere months after the war had ended, however,

\footnotetext{
18 ‘Jap. General is Acquitted’, Canberra Times, 19 October 1950, p. 4.

${ }^{19}$ Ibid.

${ }^{20}$ Yamawaki was named, for example, on the First List of War Criminals Holding Key Positions issued by the United Nations War Crimes Commission (UNWCC) in London in September 1945: United Nations War Crimes Commission, Far Eastern and Pacific Sub-Commission, 'First List of Major Japanese War Criminals Holding Key Positions', List No. 3, September 1945, NAA: A1066, H45/580/1/3. Yamawaki was also named on the first list of major war criminals sent by Australia to the UNWCC in October 1945 on the basis of his positions, including that he had been the Commander-
} 
investigators concluded that Yamawaki could, in fact, be considered responsible for specific war crimes. For example, a detailed Australian report on investigations into Japanese war crimes committed in British Borneo submitted on 28 December 1945 advised that although Yamawaki had not been located, he was considered responsible for various offences against Allied prisoners-ofwar and civilians, including a 'general policy of extortion and oppression toward the native population'. ${ }^{21}$ Yet, seemingly due to the belief that Yamawaki would be tried as a major war criminal, no action was taken to bring Yamawaki to trial for such offences at Labuan in 1945-46, where other offences committed in Borneo were generally dealt with. Indeed, by mid-1946, the Department of the Army advised the Department of External Affairs that as Yamawaki would be among those tried as major war criminals, no action would be taken by Australia to try him as a minor war criminal. ${ }^{22}$

While investigations by both Australian and British investigators into the fate of the three Australian soldiers also began immediately after the war, early reports suggested that they had accidentally drowned. A report for the SRD dated 1 December 1945 advised, for example, that the three soldiers had been 'put on a boat which was believed to be bound for Kuching, but they were never heard of again'. The report explained:

At about this time a Japanese ship was sunk by the Americans off Jambongan Island and it is quite probable that they were on that ship. There were no survivors from the ship as it [the sinking] was witnessed by the people of Jambongan. ${ }^{23}$

in-Chief in Borneo since October 1942: United Nations War Crimes Commission, Australian National Office, 'First List of Major Japanese War Criminals and Those Holding Key Positions’, NAA: A4311, 780/5.

${ }^{21}$ Report on War Crimes Investigations (British Borneo), Appendix A, pp. 7-8, NAA: A10953, 7.

${ }^{22}$ Memorandum from Secretary, Department of the Army to Secretary, Department of External Affairs, 7 May 1946 , NAA: A1067, UN46/WC/1.

${ }^{23}$ Sgt W. A. C. Russell, SRD, 'Extract from General Report of Information Pertaining Chiefly to War Criminals, Collaborators and PW's, Collected While in the Field with AGAS I and Substantiated while attached to 3 Aust PW Contact and Enquiry Unit at Sandakan', section M, NAA: B3856, 144/14/83. Likely drawing upon this report, a list of Australian military personnel missing in South East Asia dated 3 January 1946 noted that it was believed that Rudwick, McKenzie and Brandis had been on a boat to Kuching in April or May 1944 and that the boat sank without survivors: see Royal Australian Navy, Australian Military Forces, Royal Australian Air Force, Missing Personnel in South East Asia and South West Pacific Areas together with U.K. Personnel Missing in A.M.F. Area, 3 January 1946, AWM: PR84/231, item 18. 
However, on 1 July 1946 investigators reported to Army Headquarters in Melbourne that the three soldiers had, in fact, been hanged by the Japanese and their graves had been located at Jesselton. ${ }^{24}$ A copy of that message in the Army's investigations file pertaining to the three soldiers was annotated with the handwritten questions 'Is this a war crime?' and 'If so - has it been investigated?’ ${ }^{25}$ Three possible charges against those involved in the treatment, trial and execution of the soldiers were suggested in another investigator's report in November 1946, albeit informally phrased as 'illegal execution', 'ill-treatment causing injury’ and 'bad conditions causing illness'. The investigator observed that as the GOC, $37^{\text {th }}$ Army, whom he did not name, had issued the ‘[a]ctual order for execution' of the three soldiers, he could be tried on the 'major charge' of 'illegal execution'; the other two charges, however, were in his view 'unlikely to come to anything'. ${ }^{26}$

It was not until early 1947 that Yamawaki was connected to the executions of the three soldiers, as his successor as GOC in early 1945, Lt Gen Baba Masao, was initially implicated. ${ }^{27}$ By this stage, Yamawaki had not been arrested or indicted with the major war criminals at the International Military Court for the Far East in Tokyo, although further major war crimes trials were, at that stage, still being considered. It is unclear when the Australian decision to proceed against Yamawaki as a minor war criminal was taken but Army Headquarters was advised in January 1948 that the investigation of the case against him in relation to the execution of the three soldiers was 'almost complete'. ${ }^{28}$ Yamawaki was finally taken into Sugamo Prison on 2 April 1948, where the

\footnotetext{
${ }^{24}$ Message from 31 War Graves Unit to Army, Melbourne, 1 July 1946, NAA: MP742/1, 336/1/1548.

${ }^{25}$ Message from 31 War Graves Unit to Army, Melbourne, 1 July 1946 with handwritten additions, NAA: MP742/1, 336/1/1548.

26 'Report on Execution of 3 Australians at Jesselton Sep-Dec 44' by Capt F. J. Gazely, 8 British War Crimes Team, 22 November 1946, NAA: MP742/1, 336/1/1548.

${ }^{27}$ Memorandum from Lt Col. H. H. Beven, 1 Australian War Crimes Section to 2 Australian War Crimes Section (2AWCS), Tokyo, 'Execution of 3 Australians - Jesselton Gaol Borneo', 13 December 1946, NAA: MP742/1, 336/1/1548. Baba was himself tried by an Australian Military Court at Rabaul in 1947 due to his position of command responsibility over subordinates who had committed war crimes. For the trial proceedings, see NAA: A471, 81631, PARTS A-B.

${ }^{28}$ Memo from Lt Col D. L. B. Goslett, 2AWCS, Tokyo, to AHQ Melbourne, 28 January 1948, NAA: MP742/1, 336/1/1548. Separate investigations into Yamawaki's responsibility for other war crimes were also concurrently underway, including into the execution after a Japanese military trial of another Australian officer, Capt L. C. Matthews, which formed the basis (as case no. 32) for the second trial of Yamawaki at Manus in November 1950. For the trial proceedings, see NAA: A471, 81957. Another investigation into Yamawaki was also underway regarding the ill-treatment and torture of Allied prisoners-of-war at Sandakan prisoner-of-war camp: see the memorandum forwarded from 2AWCS, Tokyo to AHQ Melbourne on 14 September 1949 attaching the abstract of evidence prepared against Yamawaki and others containing two charges of ill-treatment and torture of Allied prisoners-of-war at Sandakan
} 
photographs of him above were taken. By mid-1948, the case against Yamawaki, including the charges, abstract and even the prosecuting officer's opening address had been prepared ${ }^{29}$ and the trial was slated for the Australian war crimes trials being held at Hong Kong later that year. ${ }^{30}$ Thus, although Yamawaki’s defence counsel, Nakayama Choji, told the press in February 1950 that he had not received an indictment against Yamawaki and had 'no idea at all of what the charge will be', ${ }^{31}$ this cannot be taken to suggest that either he or Yamawaki or the prosecution were actually unfamiliar with the nature of the allegations against Yamawaki and his co-accused.

Rather than inadequate evidence or a rushed assessment of it, the case was misjudged because of three quite understandable factors: firstly, the presumption, not without some due cause by the end of the war, that the Japanese routinely committed war crimes, ${ }^{32}$ including the murder of prisoners-of-war; secondly, the emotionalism that surrounds the executions of soldiers by the enemy and the desire to hold the enemy accountable for their actions; and, thirdly, the shortcomings, ambiguities and conflicting interpretations possible of international law at the time regarding espionage and the punishment of spies and a relatively uncertain grasp of how that law could be applicable to the facts of the case. As President Townley observed in private letters to Jos Francis, the Minister of the Army, in July and September 1950, before Yamawaki’s trial opened, the legal

between July 1943 and November 1943 and a third charge against Yamawaki alone for unlawfully neglecting and failing to discharge his duty as a commander to control the conduct of his subordinates in that same period whereby they committed war crimes against Allied prisoners-of-war, NAA: MP742/1, 336/1/1854. As this case appears not to have been considered at any stage for listing at Manus, it is unclear why and when the decision was made that the case would not proceed to trial.

${ }^{29}$ The 2AWCS, Tokyo advised in its 'Review of Cases Under Investigation as at 10 March 1948' that only one further month was required to secure the 'final points' of the prosecution case relating to the three soldiers and that the case was 'recommended for trial'. The review also noted that the Chinese authorities had requested Yamawaki's arrest and that the matter had been referred to the Chief of Staff, Supreme Commander of Allied Powers, for a decision on custody: see 2AWCS, Tokyo, 'Review of Cases Under Investigation as at 10 March 1948', NAA: M3344, 10. The abstract of evidence for the case to go to trial was prepared as of 26 April 1948 and a handwritten addition to the earlier 'Review of Cases', dated 27 April 1948, noted that the charges and the abstract of evidence had been prepared and that the drafting of the opening address was being prepared: see Report for Monthly Summation April 1948 from Australian Division Legal Section SCAP by Lt Col D. L. B. Goslett. Chief of Division: Australian War Memorial (AWM): AWM226, 12.

${ }^{30}$ See Memo from Lt Col D. L. B. Goslett, 2AWCS, Tokyo, to AHQ, Melbourne, 28 January 1948 in NAA: MP742/1, 336/1/1548.

${ }^{31}$ Quoted in '126 Jap War Criminal Suspects Held', The Mercury (Hobart), 21 February 1950, p. 3.

${ }^{32}$ See, for example, the belief conveyed to Australian war crimes commissioner Sir William Webb in November 1945 , in advance of any Australian convictions for committing a war crime, that there was 'already sufficient material ... to establish beyond question that ... [d]isregard by the enemy of the laws and usages of war in some important respects was widespread and continuous': Letter from Lt Col T. B. Stephens to Webb, 26 November 1945, NAA: A1066, $\mathrm{H} 45 / 580 / 1 / 2$. 
issues in the trial were of 'considerable importance and difficulty' ${ }^{33}$ and there was seemingly a 'dearth of authority' on the subject. ${ }^{34}$

There appeared to be a presumption from the very beginning of the investigation into the executions of the three Australian soldiers that they were unlawful, which undoubtedly assisted in colouring later interpretations of the facts and the law. As the initial report on the executions dated 8 July 1946 advised, members of the SRD might, in some instances, be 'lawfully treated as spies'. The report concluded, however, that '[h]aving in mind the general Japanese disregard' for international law, it was 'reasonable to assume that a war crime was committed in this case' although 'proof would be difficult'. ${ }^{35}$ By 1948, when the investigation was almost complete, Army Headquarters was advised that:

Even if it were conceded that, having regard to the circumstances, Yamawaki had some justification for trying these men as spies, the evidence that they were in fact soldiers carrying out a recognized operation of war was almost conclusive. There is, therefore, an almost irresistible inference that the accused persons acted dishonestly and without regard to the evidence. ${ }^{36}$

Even today there remains some incredulity that three Australian soldiers could be executed by the Japanese Army and such executions might have been lawful. For example, an episode of the military history documentary series In Their Footsteps screened in Australia in June 2011 on the fate of Brandis. The episode presented a rather truncated version of the facts and virtually nothing about how international law of the time might have related to them, simply claiming that the three soldiers faced a 'hastily constructed charge' of espionage at a time when decisions were being taken by the Japanese which 'reflect[ed] the coming defeat'. Dr Peter Stanley, the eminent historian from the Australian National Museum, explained in the episode that the Japanese 'denied that these three soldiers were soldiers' and instead 'treated’ them as spies. Stanley continued:

\footnotetext{
${ }^{33}$ Letter from Brig K. R. Townley to Minister for the Army, 4 July 1950: NAA, MP742/1, 336/1/2066.

${ }^{34}$ Letter from Brig K. R. Townley to Minister for the Army, 27 September 1950: NAA, MP742/1, 336/1/2066.

${ }^{35}$ See 'Hanging 3 Australians - Jesselton Gaol', 8 July 1946, NAA: MP742/1, 336/1/1548.

${ }^{36}$ Memo from Lt Col D. L. B. Goslett to AHQ Melbourne, 28 January 1948, NAA: MP742/1, 336/1/1548.
} 
We know it's ludicrous. But the Japanese were applying what we would describe, I think, as a ridiculously rigid interpretation [of spying].

Although the episode briefly referred to the Australian war crimes trials programme and showed a map which had been tendered during Yamawaki’s trial, the episode completely omitted to mention that the issue of the unlawfulness of the executions had been tested in the trial in 1950 and had failed.

\section{Espionage in International Law circa World War II}

A great deal of the uncertainty at the time about espionage and the trial and punishment of spies stemmed from the then nascent state of international law. Articles 29 and 30 of the annex to the Hague Convention Concerning the Laws and Customs of War on Land of 1907 provided a brief description of who was to be considered a spy and the declaration that a spy shall not be punished without previous trial:

Art. 29 - A person can only be considered a spy when, acting clandestinely or on false pretences, he obtains or endeavours to obtain information in the zone of operations of a belligerent, with the intention of communicating it to the hostile party. Accordingly soldiers not wearing a disguise who have penetrated into the zone of operations of the hostile army for the purpose of obtaining information are not considered spies. Similarly, the following are not considered spies: Soldiers and civilians entrusted with the delivery of despatches intended either for their own army or for the enemy's army and carrying out their mission openly. To this class likewise belong persons sent in balloons for the purpose of carrying despatches and, generally, of maintaining communications between the different parts of an army or a territory.

Art. 30 - A spy taken in the act shall not be punished without previous trial.

The Australian edition of the Manual of Military Law 1941 sought to clarify the Hague articles by stating:

Para. 164 - It follows that an officer or soldier who is discovered in the enemy's line dressed as a civilian, or wearing the enemy's uniform, may be presumed to be a spy, unless he is able to show that he had no intention of obtaining military information. 
Para. 165 - The fact that a person acting as a spy is in the naval or military service of his State does not screen him from punishment should he be apprehended by the enemy. Nor does the fact that he is in uniform make it impossible for him to be a spy. ${ }^{37}$

It was well recognised at the time that customary international law provided that persons otherwise entitled to the status of prisoners-of-war might forfeit the right to be treated as such by committing a crime such as espionage. Moreover, the punishment for espionage, after a fair and proper trial, might be death. ${ }^{38}$ Not surprisingly, Japanese military law tended to follow international law in this area. For example, article 85 of the Japanese Army Rules and Regulations held, for example, that:

One who commits espionage or who abets and aids espionage for the benefit of a hostile country shall be liable to death or imprisonment for life or imprisonment for more than five years'. ${ }^{39}$

The uncertainty about the Hague definitions of 'acting clandestinely or on false pretences' and of 'soldiers not wearing a disguise', however, meant that notwithstanding the official characterisation of the cases listed for trial at Manus Island as having a high probability of producing convictions, Australian legal officers had actually given divergent advice as to whether a war crimes charge could be properly laid against Yamawaki and his officers for their actions against the three soldiers. Maj A. D. Mackay, a legal officer with experience at the Morotai, Singapore and Hong Kong war crimes trials, strongly advised, for example, that no war crimes charges might be properly laid against Yamawaki or his staff officers. ${ }^{40}$ He observed that Yamawaki had the power to convene a military trial and confirm its verdict and the military trial held was not invalid and was a judicial trial within the meaning of international law. He considered that the three Australians fell within the definition of a spy under international law for, while two of the three were dressed in clothes of an Australian military pattern, none of them bore any badges of rank or insignia. They

\footnotetext{
${ }^{37}$ Chapter XIV, Australian edition of the Manual of Military Law 1941, Canberra: Commonwealth Government Printer, 1941.

${ }^{38}$ See William E. S. Flory, Prisoners of War: A Study in the Development of International Law (Washington D.C.: American Council on Public Affairs, 1942), at 37. See also para 158, chapter XIV, Manual of Military Law 1941.

${ }^{39}$ See the extracts of Japanese law translated into English and tendered as evidence in the second trial of Yamawaki at Manus in NAA: A471, 81957.

${ }^{40}$ See 'Execution of Lt Rudwick, Sgts McKenzie, Brandis at Jesselton Jail, Borneo, December 1944' in NAA: MP742/1, 336/1/1548.
} 
did not carry any identity discs or other means of proving their identity and therefore could not be classed as being in military uniform. He pointed out that Rudwick had, in fact, admitted that they discarded all their badges and insignia to avoid recognition as Australian soldiers. Moreover, they had landed secretly from an Allied submarine and had observed Japanese shipping and other movements and then conveyed this information by radio to the Allied Forces. In his view, there was evidence on which the Japanese military court could convict the three on a charge of espionage and that death by hanging or shooting was a 'recognised and usual punishment for spying'. Mackay concluded that 'no war crimes charges' could be laid against Yamawaki or any members of the Japanese court which had tried the three Australian soldiers or any of the 'actual executioners'. Mackay’s advice was prescient of the Court's subsequent demolition of the prosecution case against Yamawaki and his co-accused, which was drawn from the alternate legal advice given.

Maj H. F. Dick, a legal officer with trial experience at Rabaul and Singapore, similarly advised that the Japanese military court had been properly convened and appeared to have been 'regular in form'. ${ }^{41}$ He entirely differed from Mackay, however, on the issue of whether the three Australians fell within the definition of a spy. He acknowledged that the definition of a spy was 'very loose' but considered that the evidence established 'beyond all doubt' that the Australians were not spies. In particular, and unlike Mackay, he attached no importance to their lack of identification, which he thought was immaterial given that the prisoners had declared themselves at all times to be Australian soldiers and had given their names and ranks; Rudwick and McKenzie were dressed in Australian uniform and the loss of Brandis’ uniform had been explained; and they were carrying arms openly and their arms, ammunition and other equipment were 'plainly of military pattern'. Dick concluded that the Japanese court had acted in gross neglect of their duty and, in finding that the Australians were guilty of espionage, had acted 'dishonestly'. Since the Japanese court had not acted in a judicial manner, when Yamawaki confirmed the findings and sentences, he had acted either dishonestly or in neglect of his duty. He concluded, therefore, that Yamawaki and

\footnotetext{
${ }^{41}$ See ‘Subject: War Crimes Borneo’: Execution of 3 Australian Soldiers Jesselton Gaol’, NAA: MP742/1, 336/1/1548.
} 
his officers might be charged with murder, although he conceded that he knew of no precedent for proffering a murder charge against members of a properly-convened court who acted within their jurisdiction. He nonetheless saw ‘no legal reason’ why the charge should not succeed.

That Dick’s legal advice was accepted over that of Mackay can perhaps be explained by the fact that Dick’s advice was far more detailed and lengthy, and perhaps more convincing, than that of Mackay and, above all, it was in tune with the presumption that a war crime had been committed with the executions of the three soldiers and that Yamawaki and his co-accused should be punished for the deaths.

While the official view of the evidence against Yamawaki must have been that it formed at least a prima facie case, there is some indication that the those legal officers who had the duty of preparing for the trial recognised that the case was not as strong as it appeared to others. The most obvious was the hedging of bets by proffering the charge in the alternative: while the accused were principally charged with murder, they were charged in the alternative with a violation of the laws of usages of war. The charges read:

Committing a war crime, that is to say murder in that they at Jesselton in Borneo in 1944 murdered three members of the Military Forces of the Commonwealth of Australia; (Alternative to First Charge) Committing a war crime, that is to say, a violation of the laws and usages of war in that they at Jesselton in Borneo in 1944 being officers of the Imperial Japanese Army concerned with the trial of three members of the Military Forces of the Commonwealth of Australia unlawfully disregarded and failed to discharge their duty to try the said persons in accordance with the rules of international law whereby the said persons were unlawfully executed. ${ }^{42}$

This provision of the charges in the alternative meant that if all the elements of the charge of murder could not be proved beyond reasonable doubt, it was still open to find the accused guilty of the alternative charge. In addition, both charges described the victims not as prisoners-of-war but as 'members of the Military Forces of the Commonwealth of Australia'. This was most unusual choice of material particular for the charge, as the practice across the Australian war crimes trials programme was to describe captured service personnel held by the Japanese as prisoners-of-war. Of

\footnotetext{
${ }^{42}$ Underlining added for emphasis.
} 
the 26 Manus Island trials in total, for example, nearly all of which concerned captured service personnel, this is the only trial which described the victims in the charges as 'members of the Military Forces' instead of as prisoners-of-war. The inescapable conclusion is that the legal staff preparing for the trial knew that to describe the three victims as prisoners-of-war in the charge would force the prosecuting officer to prove that they were prisoners-of-war, thereby allowing Yamawaki's defence counsel to present the defence that the prisoners were not prisoners-of-war, as they had forfeited their rights to be treated as such by their espionage. As the charge actually stood, however, this issue of their status was effectively avoided, as they were unquestionably 'members of the Military Forces of the Commonwealth of Australia'. If the trial had continued on the charge as drafted, the defence counsel would have had to present a far more difficult defence: that the Japanese trial had been fair and proper according to international law and not a 'mock' or 'sham' trial. In the end, however, the defence counsel did not have to present any defence to the charge, as his application to dismiss the charges was successful on the basis that the prosecution evidence had not established that an offence had been committed.

\section{The Court's Reasoning that No War Crime had been Committed}

In dismissing the charges against Yamawaki and his co-accused, the Court was firm that it was not sitting as a court of appeal of any form from the Japanese military court's earlier decision; that is, the Court advised that it was:

not sitting ... to decide whether the Japanese military court's decision was right or wrong; it was sitting to determine whether, if the prosecution's argument on the law was correct, that the trial held was a 'mere sham'. ${ }^{43}$

As it was the practice in the Australian war crimes trials not to give written reasons for decisions, it is difficult to ascertain the precise facts accepted and the laws applied by the Court. However, the factual and legal issues which the Court perhaps believed were at the core of the case can be

\footnotetext{
${ }^{43}$ NAA: A471, 81956.
} 
detected in the submissions made in support and in objection to the application to dismiss the charges and, in particular, in the Court's extensive, and surprisingly inquisitorial, oral questioning on the application. These key issues appeared to be: whether there had been an excess or abuse of jurisdiction by the Japanese military court and, if so, how this might affect the general principle of immunity of judicial officials and, above all, how the Japanese military court might have been expected to perceive the status of the three soldiers given their lack of identification.

In his application to dismiss the charges, the defence counsel advised that, in his view, the 'real question' was 'whether the [Japanese military] Court was a real court and the trial a real trial in accordance with Japanese military law'. He argued that if the answer was 'yes', then the accused had no case to answer, as the prosecution case had not disclosed an offence under the War Crimes Act 1945 or in international law. He submitted that the Japanese military court (gunritsu kaigi) possessed the jurisdiction to try the prisoners for espionage, had abided by the requirements of Japanese military law for the trial, made no distinction between Japanese and foreign nationals and was competent. He observed that the common law of England and Australia guaranteed the immunity of judicial officers and cited the principle that:

no action is cognizable at Common Law or Statute in which a judge or judicial officer is liable personally for any act done by him in his judicial capacity.

He conceded that if judicial authority was exercised within legal limits but, at the same time, with 'excessive severity or cruelty', the 'abuse' of the jurisdiction might amount to 'excess' of jurisdiction. In his view, however, there was no evidence of such 'excess' in this case. ${ }^{44}$ In relation to the trial itself, he observed that international law did not provide a 'fixed form or procedure' which could be regarded as 'indispensable' to a 'trial'. He thought that the prosecuting officer

\footnotetext{
${ }^{44}$ He referred the Court to the extract from the judgment of Lord Mansfield in the case of Wall v Macnamara (1779) 1 T.R. 536, which was discussed in para 37, chapter VIII of the Australian edition of the Manual of Military Law 1941, as amended: 'Thus the principal inquiry to be made by a court of justice is, how the heart stood; and if there appears to be nothing wrong there great latitude will be allowed for misapprehension or mistake. But, on the other hand, if the heart is wrong, if cruelty, malice, and oppression appear to have occasioned or aggravated the imprisonment or other injury complained of, they shall not cover themselves with the thin veil of legal forms, nor escape under cover of a justification, the most technically regular, from that punishment which it is your province and your duty to inflict on so scandalous an abuse of public trust'. Italics in the original.
} 
would agree with him that the 'minimum requisite' of a 'fair trial' was one in which both sides were given a:

reasonable opportunity to present their contentions, and in which the tribunal impartially decides between the two.

While the prosecuting officer had argued in presenting his case that the prisoners had not been permitted to present their defence to the charge of espionage, and that this derogated from the requirements of a proper and fair trial in international law, the defence counsel pointed out that the prisoners had, in fact, pleaded guilty at trial to the charge of espionage; had stated that they had no evidence that they wished to call; had stated that the facts were as had been alleged by the prosecutor; and that, when they were given the opportunity to address the Court, they had declined it. He submitted, therefore, that trial by the Japanese military court had not been shown to be unfair. In relation to Yamawaki's roles as the convening and confirming officer, he described Yamawaki as being like a GOC anywhere in any army; that is, he was not a lawyer and in legal matters, he acted on the advice of his staff officer, Matsumoto. He submitted that the evidence showed Yamawaki to have acted in the 'utmost good faith' and therefore to have been guilty of 'no offence whatever'. He concluded, therefore, that Yamawaki and his co-accused were the convening officer and members of a legally-convened and properly-constituted Japanese military court; that such court had the jurisdiction to try the prisoners; and that there was no 'excess' of jurisdiction. Therefore, it was:

not within the province of this War Crimes Court to examine the evidence or the reasons for the decision of the Japanese court, the War Crimes Court should merely satisfy itself that such Japanese court had jurisdiction, and was a legally constituted court and not a mere sham or fiction, and if so satisfied, acquit the accused.

In support of his submissions he asked the advisory officer to read several authorities to the Court on the competence of the Japanese military court, on jurisdiction and on the effect of judicial immunity. The cases cited included Haddon v Evans 35 TLR (1919) 642, which held that:

a military officer is liable to an action for damages if in excess of his jurisdiction he commits an act which amounts to false imprisonment or other common law wrong, even though he purports to act in the course of military discipline; but if his act is within his 
jurisdiction and is done in the course of military discipline no action will lie on the ground only that the act has been done maliciously and without reasonable and probable cause.

In response to the defence counsel's application to dismiss the charges, the prosecuting officer advised that he did not agree with the submission that the 'real question' was whether the Court was a real court and the trial a real trial in accordance with Japanese military law; rather, it was whether there had been a proper trial and a fair trial in accordance with international law. He admitted that the Japanese military court did have jurisdiction over the soldiers but submitted that the jurisdiction had been abused because the trial was unfair and improper. He acknowledged the defence's citation of Haddon v Evans but argued that the case in question dealt not with a court or tribunal but with an officer acting in the course of his military duties. He referred the Court to para 53, chapter VIII of the Manual of Military Law 1941, as amended:

There are several authorities which show that where the death of a person is caused by some act of an officer done without jurisdiction, the officer is criminally responsible. Thus on the Devon Militia case being cited in Warden v. Bailey, Heath J., expressed his opinion that, if the plaintiff in that action had died under the punishment inflicted by order of the court-martial, all the members of the court would have been liable to be hanged for murder.

When the Court pointed out the obvious weak point in that submission - that liability in that case arose because the court-martial acted without jurisdiction and they were not 'clothed in any judicial immunity' - the prosecuting officer argued that it was because the court-martial acted 'without jurisdiction in inflicting an excessive punishment'. In further support of his argument that excessive punishment could affect jurisdiction, he cited the Governor Wall case, ${ }^{45}$ which involved the murder of a Serjeant Armstrong on whom Wall had ordered eight hundred lashes to be inflicted with the unusual instrument of rope; moreover, the beating was done with such cruelty, with Wall standing by urging 'increased severity', that Armstrong died shortly afterwards. The court in that case directed the jury that there was 'certainly ground to infer malice' and Wall was found guilty of murder and hanged. The Court suggested to the prosecuting officer, however, that Wall's liability

\footnotetext{
${ }^{45}$ This was $R$ v Wall (1802) 28 State Trials 51.
} 
arose in that case because while Wall had jurisdiction to sentence a man to be flogged, he did not have jurisdiction to sentence a man to death; Wall could not, therefore, under a guise of imposing a sentence of flogging, impose such a sentence of flogging that could not help but cause his death. The Court questioned whether the word 'malicious' was, in this case, used in the legal sense of an act done intentionally. The prosecuting officer argued that 'malicious' in this case also meant 'with a bad motive' and reiterated his view that it was simply a question of whether a court was 'actuated by malice'. The Court repeatedly suggested, however, that:

surely there must be some evidence - if there is jurisdiction in that Court - there must be some evidence of a wicked mind in the Court and, of course, the Convening officer, the Prosecutor also, if the Prosecutor can be said to have had any part in it.

In response, the prosecuting officer submitted that evidence of a wicked mind had been disclosed. He pointed out that it was not the first time that a case involving the actions of a Japanese courtmartial had come before a war crimes tribunal. He advised that several trials, including two earlier Australian trials, as reported in the United Nations War Crimes Commission's Law Reports of Trials of War Criminals, had examined the issue of when an alleged offence had been carried out as a judicial act. ${ }^{46}$ He returned to his core argument that the Japanese trial had not been fair or proper, by referring the Court to the explanatory notes contained in volume XV of the Law Reports of Trials of War Criminals, which observed that:

It has sometimes been pleaded that a victim of an alleged war crime, sometimes a prisoner of war and sometimes an inhabitant of occupied territory, had himself engaged in an act of espionage or a war crime and was punished in accordance with international law for having committed these offences. This plea has been allowed to prevail if it has been shown that the victim was accorded a fair trial. Just as in municipal law systems a hanging or imprisonment following upon a legal sentence pronounced in court does not involve the hangman or prison warder in subsequent criminal proceedings so under international law the proof that a prisoner of war or a civilian inhabitant of an occupied

\footnotetext{
46 The prosecuting officer cited the trial of Lt Gen Sawada Shigeru and three others, United States Military Commission, Shanghai, 27 February-15 April 1946, Law Reports of Trials of War Criminals, vol. 5, pp. 1-24; the trial of Sgt Maj Ōhashi Shigeru and six others, Australian Military Court, Rabaul (R26 trial), 20-23 March 1946, Law Reports of Trials of War Criminals, vol. 5, pp. 25-31; the trial of Capt Shinohara Eitarō and two others, Australian Military Court, Rabaul, 30 March-1 April 1946, Law Reports of Trials of War Criminals, vol. 5, pp. 32-36; the trial of Lt Gen Isayama Harukei and seven others, United States Military Commission, Shanghai, 1-25 July 1946, Law Reports of Trials of War Criminals, vol. 5, pp. 60-65; and the trial of Gen Tanaka Hisakasu, United States Military Commission, Shanghai, 13 August-3 September 1946, Law Reports of Trials of War Criminals, vol. 5, pp. 66-81.
} 
territory has been executed or otherwise punished only after proceedings possessing the characteristics of a fair trial will constitute a defence to a charge of war criminality brought against persons involved in the inflicting of that punishment, such as a prosecutor, a judge, a prison warder or an executioner. ${ }^{47}$

The prosecuting officer submitted that the 'main principle' arising out of the cases reported in the Law Reports of Trials of War Criminals was that of a 'fair trial', which in his view meant that the accused should know the charge that is against them; the proceedings should be interpreted to them; and the accused should have a full opportunity of making their defence. Most importantly, in his view, the court trying the accused should approach the trial 'unprejudiced', the convening officer, the confirming officer, the court and the prosecutor should act with 'honesty and fairness' and that the trial should 'not be, in any way, a false Trial'; that is, a trial with the 'form of a Trial but in which, in reality, the accused persons are being what the Americans call "railroaded”'.

While it appeared to the Court that the prosecuting officer was contending that the evidence before the Japanese military court that the three soldiers were 'not spies' was 'so overwhelming that no reasonable man could honestly arrive at a contrary conclusion', the Court reminded him that they had to look at the issue from the position of the Japanese military court. They pointed out that it was a matter of common military knowledge that Australian soldiers at that period were:

required to wear, at all times, identity discs which had engraved thereon their regimental number, their name, religion and their blood group, and also they were required to carry a pay book. As a matter of fact, it was for the purpose of withholding information from the enemy if a man was captured, that pay ciphers were used instead of the actual place of pay. Also they were required to wear the badges of rank to which they were entitled.

The prosecuting officer responded that he thought that any armed Australians in Borneo 'would and could only be troops' and pointed out that it had not been argued that the three soldiers were 'disguised as anything', as the only effective disguises would be as natives or Japanese, both of which were 'impracticable'. He pointed out that while 'badges of rank, identity disks and paybooks' certainly were 'normally carried' by troops, 'those things, as in this instance and others, were left behind in forward areas at times'. The Court pointed out that in their recollection, as far as identity

\footnotetext{
${ }^{47}$ Law Reports of Trials of War Criminals, vol. 15, pp. 161-62. Underlining added for emphasis.
} 
disks were concerned, it was 'compulsory' to wear them in forward areas, which is where they were 'especially required'; badges of rank, too, were also universally worn by officers. In response, the prosecuting officer suggested that, in fact, badges of rank were not worn universally; they were often taken off, for instance, because of the activities of snipers. He submitted that all that international law required was that soldiers should be dressed in uniform and, if carrying arms, carrying them openly; if they were captured, they should give their name and rank. He knew of no provision that soldiers had to carry means of identification or badges of rank. The Court reminded the prosecuting officer that they were considering the knowledge of the members of the Japanese military court regarding to what could be expected in relation to persons who alleged that they were Australian soldiers, a lot of whom had been taken prisoner-of-war by 1944. They questioned whether a member of such a court would be entitled to say to himself when taking part in the matter:

Well now, this man undoubtedly was captured in uniform, when captured was bearing arms and bearing them openly, and undoubtedly they did have supplies of a military nature; but I know that normally an Australian soldier wears an identity disk, that normally an Australian officer or N.C.O. wears his badges of rank, and normally members of the Australian Military Forces carry paybooks which carry an identifying photography and also his name and regimental number and so on.

The prosecuting officer reiterated that the accused must have known that the prisoners were Australian soldiers but 'chose to call them spies' and afforded them a 'mockery of a trial as spies'.

The Court suggested, however, it seemed to them that an inference could be drawn that on:

one side they [the Japanese military court] had the evidence with regard to uniforms, weapons and so on, then they had the evidence of the absence of identity discs, pay books, no certificates ... and of badges of rank and they had to weigh those one against the other.

The Court advised that it seemed that the prosecution had to establish beyond reasonable doubt that not only was the decision of the Japanese military court 'entirely erroneous' but that it was, in fact, 'dishonest to the extent of rendering the whole of the proceedings a sham'. Almost as an aside, the 
Court advised that they did not think that judicial immunity as a principle could be applied in its entirety to a tribunal like the Japanese military court, as if it could be so applied, then it meant that:

simply by going through a form of trial they could commit murders - absolutely unjustified killings, I mean - and impose other sentences such as imprisonment without any legal justification or moral justification whatsoever.

The Court thus thought it appropriate that the decisions of 'such Tribunals' be questioned in proceedings such as that underway before them. After twenty-two pages of questioning on these issues related to the decision of the Japanese military court, however, the Court upheld the defence counsel’s application and dismissed the charges against Yamawaki and his co-accused.

\section{The Failed Prosecution in Hindsight}

After the trial, Maj George Dickinson, the Australian legal officer who was appointed to assist the defence during the Manus Island trials, a Sydney barrister in civilian life, attempted to articulate what he saw as the reason for the failed prosecution of Yamawaki and his co-accused. Dickinson explained in an article for the Sydney Morning Herald in June 1951 that the Court had acquitted the accused on the ground that the:

prosecution had disclosed [in its evidence] no offence known to the War Crimes Act 1945 or International Law.

He continued:

No provision exists in the War Crimes Act for overall responsibility for unlawful killing; consequently, nearly every accused was charged with murder in circumstances which could only result in a number of cases in acquittal. ${ }^{48}$

Like the early investigators and later critics, Dickinson seemed to be operating from the presumption that a crime had been committed with the executions of the three Australian soldiers

\footnotetext{
${ }^{48}$ George Dickinson, 'How Justice was Done on Manus I.', Sydney Morning Herald, 1 June 1951, p. 2. See also George Dickinson, 'Manus Island Trials: Japanese War Criminals Arraigned', 38(1) Royal Australian Historical Society (1952), 67-77, at 68-9.
} 
but the limitations of the War Crimes Act 1945 and international law meant that the accused could only be charged with murder, even though this charge, given the facts, 'could only result' in acquittal. Dickinson's conclusion may appear to be convincing on a pure statutory analysis of the War Crimes Act 1945, which explicitly mentioned in its definition of a war crime, for example, such offences as 'murder and massacre', 'putting hostages to death' and 'directions to give no quarter' but did not specifically list any other form of unlawful killing. ${ }^{49}$ However, any apparent restriction to a charge of 'murder', the existence of which Dickinson had implied, did not preclude more than 40 of the Australian war crimes trials being advised that they could lawfully find accused persons charged with murder to be guilty of the lesser charge of manslaughter and a number of them, in fact, handing down that finding. As President Townley had himself advised the Court in the Morotai M6 trial in 1945, where he was assigned as the judge-advocate, if the Court arrived at the conclusion that:

the facts do not support the charge of murder, then you are, in my opinion, entitled to convict them [the accused] of a charge of unlawful killing which is, in effect, a charge of what is commonly known as manslaughter. ${ }^{50}$

Moreover, other Australian trials were specifically convened on charges of unlawful killing, such as being 'in violation of the laws and usages of war ... concerned in the unlawful killing of ... prisoners of war' or 'in violation of the laws and usages of war unlawfully ordered and caused to be shot and killed ... prisoners of war'.

By contrast, for the noted Australian historian D. C. S. Sissons, who served as an interpreter at the Morotai trials and who studied the war crimes trials for decades afterwards, the failed prosecution of Yamawaki did not demonstrate the limitations of the law but the proper operation of the same. In his view, Yamawaki's acquittal was merely one example of the 'participants [in the

\footnotetext{
${ }^{49}$ Section 3 of the War Crimes Act 1945 defined 'war crime' as 'a violation of the laws and usages of war; or any war crime within the meaning of the instrument of appointment of the Board of Enquiry appointed on the third day of September, One thousand nine hundred and four-five, under National Security (Inquiries) Regulations (Being Statutory Rules 1941, No. 35, as amended by Statutory Rules 1941, Nos. 74 and 114 and Statutory Rules 1942, No. 273)'. The instrument of appointment included a list of war crimes based, with some amendments, on the list from the 1919 Commission of Responsibilities and included, for example, at no. ii 'murder and massacre'.

${ }^{50}$ For the trial proceedings, see NAA: A471, 80717.
} 
war crimes trials] ... endeavouring to operate the war crimes system with restraint' rather than as a mere process to produce convictions and executions. ${ }^{51}$

The real problem in this case was not the limitations of the law, although they played a part, but the limitations of the facts: no matter how unsavoury a proposition it is to some, even today, the Court adopted the argument that no war crime under the law as it was at the time had been committed. The real offenders in this case, if any can be characterised as such, were the senior officers of the SRD who did not select the personnel with the right training and skills for the Python II operation and failed to properly instruct them on how they ought to best safely perform intelligence reconnaissance work in Japanese-occupied territory - in as much as that was possible and particularly that their means of identification should not be discarded lest they be taken as spies. Maj F. G. L. Chester, the officer-in-charge already in Borneo with the Python I party, advised in an administrative report dated 5 February 1944, for example, that he was 'extremely disappointed with the lack of care taken in the choosing of personnel' for Python II and that, in his view, the 'lastminute selection of merely healthy bodies’ as reinforcements was 'ill-timed and useless’. In support, he pointed to the fate of Brandis. He emphasised that the 'golden rules of the jungle' - such as, 'if lost stay until found' - had to be 'told to each and every man'. He observed that these 'rules':

may appear childish, but are NOT, in view of the unfortunate loss of BRANDIS, who apparantly [sic] did NOT know them. ${ }^{52}$

One draft of the history of the Python operation was even more scathing, pointing out that Brandis’ ignorance of how to operate in the jungle 'pointed to glaring anomalies in the training system, anomalies which led to needless loss of life'. ${ }^{53}$

Interestingly, there is evidence to suggest that the strength and prospects of a number of the cases listed for trial at Manus Island, not only the two cases concerning Yamawaki, were similarly

\footnotetext{
${ }^{51}$ David Sissons, ‘The Trials: Were They Justice or Vengeance’, Sydney Morning Herald, 16 Aug 1985, p. 9.

${ }^{52}$ Capitals in the original. Maj F. G. L. Chester, Administrative Report, 5 February 1944, NAA: A3269, A7/A.

${ }^{53}$ Draft History of SOA [Special Operations Australia], "Python" Operation, p. 4, NAA: A3269, A7/A. This section on Brandis was crossed out. Curiously, the draft history did not account at all for the loss of Rudwick and McKenzie.
} 
misjudged. As the Australian Associated Press correspondent on Manus pointed out in February 1951, the Court had by then acquitted 25 of the 96 suspects tried. The correspondent reported:

In many cases the Court did not call on the defence. The prosecution had been unable to tender sufficient evidence to make out a case against the accused. The Court discharged Gen. Masataka Yamawaki without calling on him to say one word in his defence. ${ }^{54}$

In the end, the Manus Island trials, if judged just against the criteria of producing convictions and death sentences, were a relative failure, especially when compared to the Australian war crimes trials overall. Of the 91 individual persons charged at Manus with 142 charges, only 77 convictions were recorded, a conviction rate of about 54 per cent. Moreover, of the 14 sentences of death imposed, only five such sentences were 'executed'; the remainder were commuted in the petition (appeal) process after trial to sentences of imprisonment.

\begin{tabular}{|c|c|c|c|c|c|}
\hline $\begin{array}{c}\text { Number of } \\
\text { Accused Tried }\end{array}$ & $\begin{array}{c}\text { Number of } \\
\text { Charges }\end{array}$ & Convictions & Acquittals & \multicolumn{2}{|c|}{$\begin{array}{c}\text { Death Sentences } \\
\text { Imposed and } \\
\text { Carried out }\end{array}$} \\
\hline $\begin{array}{c}113 \\
\text { (91 individuals) }\end{array}$ & 142 & 77 & 65 & 14 & 5 \\
\hline
\end{tabular}

\begin{tabular}{|c|c|c|}
\hline Trial Location & Conviction Rate & $\begin{array}{c}\text { Executions (\% of } \\
\text { individuals tried) }\end{array}$ \\
\hline Manus Island & $54.22 \%$ & $5.49 \%$ \\
\hline All Australian trials & $\sim 67.65 \%$ & $16.98 \%$ \\
\hline
\end{tabular}

These figures were much lower than the overall rate of conviction and the number of death sentences carried out as a percentage of individuals tried. While there are other compelling reasons to explain why, after the Manus Island trials, the Australian war crimes trials programme ceased, it is more than probable that the time and expense, which were over-estimate and budget, as well as the unexpected prosecution failures played a role in the decision.

As for Yamawaki, the similar charges he faced in his second trial at Manus Island relating to the execution of another Australian officer were also dismissed. Before he departed Manus Island

\footnotetext{
54 'Manus War Crimes Trials are Dragging to a Close’, The Mercury (Hobart), 2 February 1951, p. 3.
} 
for Japan, Yamawaki sought and was granted permission in December 1950 to be allowed to meet with some of the convicted war criminals by then serving their sentences in the War Criminals Compound, including Gen Imamura Hitoshi, former GOC, $8^{\text {th }}$ Army Group, and some of his '[f]ormer comrades of North Borneo'. He confided to the Australian authorities that as he did not know the names of his subordinates, he was happy for Japanese and Formosan representatives from among them to be selected by Imamura. ${ }^{55}$ Yamawaki presumably met with those selected, Matsutaka Katsushi ${ }^{56}$ and Fujikawa Tetsuo, ${ }^{57}$ both former subordinates, on the date permitted in January 1951, just before he was repatriated to Japan at the end of the month. ${ }^{58}$ Yamawaki died in 1974 and today he is somewhat hyperbolically celebrated, at least by one Japanese author, as the 'last full general who loved peace'. ${ }^{59}$ Regrettably, while the author includes discussion in his book of Yamawaki's lengthy detention as a war crimes suspect in Sugamo Prison, there is little said about his trials at Manus Island.

\footnotetext{
${ }^{55}$ Yamawaki's petition to Commandant, 19 December 1950, NAA: MP375/11, 10.

${ }^{56}$ Sgt Maj Matsutaka Katsushi had been tried at Labuan in January 1946 for ill-treating Allied prisoners-of-war and internees at Kuching between May 1942 and September 1945. Matsutaka was then serving a sentence of 7 years' imprisonment. For the trial proceedings, see NAA: A471, 80754.

${ }^{57}$ Gd Fujikawa Tetsuo had been tried at Labuan in December 1945 for massacring about 15 Allied prisoners-of-war at Miri in June 1945. Fujikawa had been sentenced to death but the sentence was commuted to 10 years' imprisonment with hard labour, which he was then serving. For the trial proceedings, see NAA: A471, 81204.

${ }^{58}$ Letter from Adjutant-General, AHQ Melbourne to HQ BCOF, 6 February 1951, AWM: AWM54, 779/9/18.

${ }^{59}$ See the English phrase used on the cover page of Myôjin Yoshimasa, Heiwa o aishita saigo no rikugun taishô Yamawaki Masataka [The Last Army General Who Loved Peace, Yamawaki Masataka] (Kôchi: Riburu shuppan, 2006).
} 


\section{Archival Sources}

National Archives of Australia, Canberra and Melbourne

A471 80717. [War Crimes - Military Tribunal - ASAOKA Toshio (Lieutenant) : SUSUKI Asamasa (Private) : OICHI Tuichi (Private) : Unit - 211th Regiment, 32nd Japanese Division : Place and date of Tribunal - Morotai, 13 December 1945].

A471, 80754. [War Crimes - Military Tribunal - SHOJI Kuraji (Sergeant) : MATSUTAKE Katsuhi (Sergeant) : KOGO Shigeru (Sergeant) : ASAKUSA Katsuji (Sergeant) : INAGAKI Tetsuo (Lieutenant) : KUBO Akihiko (Lieutenant) NAGATA Tomio aka KYOGAWA : KYOSE Norisuke : MATSUDA Takeishi : OKAMOTO Kiemel : ISHIMOTO Yoshio : TSUDA Seiji : FUJIMOTO Yoshio : TAGAWA Nobuyuki : SUZUKI Noboru : YASUMOTO Yoshio : HAYAMA Takeo : MATSUDA Buichi : ISHII Hideo : TAKAMURA Shoji : TOKUDA Masatake : MATSUBAYASHI Takeo : TAKAMI Tsuneo : KIMURA Seijiro : NAGAYOSHI Seichi : KAWAMURA Katsuo : KANEKO Shigemori : IMAGAWA Masamune : KATO Tadao : FUJIMURA Shigeru : TAKENAGA Shigematsu : KOBAYASHI Teruo : NAGAMURA Eiki : KASAMA Eiji : OKOBAYASHI Takemitsu : FUJITA Yoshio : TOMIBAYASHI Teruo : YOSHIDA Koichi : OKAMOTO Shozo : SIGIYAMA Seichi : KOIKE Yasushi : SHIMIZU Kanji (Rank for above servicemen: Guards) : (Prisoner of War Camp Lintang Barracks, Kuching Sarawak) : Place and date of Tribunal - Morotai, 22-31 January 1946].

A471, 81204. [War Crimes - Military Tribunal - HIROTA Selichi AWC 728 : KANASHIGE Shokichi AWC 748 : FUJIKAWA Tetsuo AWC 704 : HIRAYAMA Hideo AWC 725 : NAKAYAMA Kenichi AWC 795 : KAWAMURA Teruhoshi AWC 752 : UMEMURA Susumu AWC 848 : MIYAMOTO Fumio : KUMADA Norihara : Date and Place of Tribunal - Labuan, 8 December 1945].

A471, 81631, PARTS A-B. [War Crimes - Military Tribunal - BABA Masao (Lieutenant-General) : Unit - 27th Japanese Army : Date and Place of Tribunal - Rabaul, 28 May and 2 June 1947].

A471, 81956. [War Crimes - Military Tribunal - YAMAWAKI Masataka (General): MAEDA Tashimitsu [sic] (Lieutenant-Colonel): MATSUMOTO Tomeyoshi (Captain): KANAZAWA Kisou (Lieutenant): Unit - 37th Japanese Army: Place and date of Tribunal - Manus, 16-18 October 1950].

A471, 81957. [War Crimes - Military Tribunal - YAMAWAKI Masataka (General): WATANABE Haruo (Captain): Unit - Borneo Defence Army: Place and date of Tribunal - Manus, 30 October to 16 November 1950].

A816, 19/304/447. Continuance of war crimes investigation and trials of Japanese suspects, minor war criminals.

A1066, H45/580/1/2. Atrocities: War Crimes Progress Report, July 1945.

A1066, H45/580/1/3. United Nations War Crimes Commission: Lists of War Criminals.

A1067, UN46/WC/1. War Crimes. Major Japanese War Criminals.

A1838, 3103/10/13/2 PART 1. Japan - Japanese war criminals - Australian war trials.

A3269, A7/A. [Borneo -] PYTHON, copy I [British North Borneo].

A4311, 780/5. United Nations War Crimes Commission [UNWCC] - Australian National Office - First List of major Japanese War Criminals and those holding key positions [Folder B]

A10953, 7. Report of War Crimes Investigations (British Borneo).

B3856, 144/14/83. Services Reconnaissance Detachment - report on Prisoners of War Borneo.

M3344, 10. D [Doris] Heath - 2 Australian War Crimes Section - Tokyo.

MP375/11, 10. YAMAWAKI, Masataka. Item contains 2 photos.

MP742/1, 336/1/1548. Jesselton Gaol, Borneo - Execution of Lieutenant Rudwick and others.

MP742/1, 336/1/1854. War crimes - Execution of Captain L C Matthews [and ill-treatment of prisoners of war by Kempei Tai at Sandakan].

MP742/1, 336/1/2066. Australian war crimes trials - Manus - Legal references [request for Brigadier Townley in connection with cases against General Yamawaki, Masataka and others].

\section{The Australian War Memorial}

AWM54, 779/9/18. [Prisoners of War and Internees - Exchange and Repatriation:] Repatriation of Japanese Prisoners of War: Suspension of sentences of imprisonment; lists of war criminals; petitions from Japanese nationals.

AWM166, 4. AG Coord 221 - Trial of Japanese suspect minor war criminals (April-July).

AWM226, 12. [Records of war crimes enquiries and trials, 1939-45 War] General HQ, Supreme Commander for the Allied Powers, Legal Section - Monthly Summation (Statistics and Reports).

PR84/231, item 18. Private Record of Jackson, Harold W S (Lieutenant Colonel, MBE, ED, 3 PW Contact and Enquiry Unit, AIF b: 1914) Contact and Enquiry Unit, AIF b: 1914).

\section{Reference List}

‘126 Jap War Criminal Suspects Held’, The Mercury (Hobart), 21 February 1950, p. 3.

'Australian Policy on War Trials', The West Australian, 25 February 1950, p. 1. 
Blakeney, Ben Bruce, 'The Japanese High Command’, 9(1) Military Affairs (Summer 1945), pp. 95-113.

Dickinson, George, 'How Justice was Done on Manus I.’, Sydney Morning Herald, 1 June 1951, p. 2.

Dickinson, George, 'Manus Island Trials: Japanese War Criminals Arraigned', Royal Australian Historical Society, vol. 38, no. 1, 1952, pp. 67-77.

Flory, William E. S., Prisoners of War: A Study in the Development of International Law (Washington D.C.: American Council on Public Affairs, 1942).

Feuer, A. B., Australian Commandos: Their Secret War Against the Japanese in World War II (Mechanicsburg, PA: Stackpole, 2006).

Fry, Thomas P., 'The International and National Competence of Australian Parliaments to Legislate in Respect of Extra-Territorial Crime (Including War Crimes)', University of Queensland Papers, Faculty of Law, vol. 1, no. 2, 18 October 1947, pp. 1-90.

'Japanese Hopes for War Trials', The Advertiser (Adelaide), 3 June 1950, p. 4.

'Jap. General is Acquitted', Canberra Times, 19 October 1950, p. 4.

'Manus War Crimes Trials are Dragging to a Close', The Mercury (Hobart), 2 February 1951, p. 3.

Manual of Military Law 1941, Australian edition, Canberra: Commonwealth Government Printer, 1941.

'No Hangman Post at War Crimes Trials', Sydney Morning Herald, 7 June 1950, p. 3.

Sissons, David, 'The Trials: Were They Justice or Vengeance’, Sydney Morning Herald, 16 Aug 1985, p. 9

Yoshimasa, Myôjin, Heiwa o aishita saigo no rikugun taishô Yamawaki Masataka [The Last Army General Who Loved Peace, Yamawaki Masataka] (Kôchi: Riburu shuppan, 2006). 